\title{
THE INFLUENCE OF EDUCATION, WELFARE AND RESIDENTIAL AREA ON ADOLESCENT MARRIAGES IN SOUTH KALIMANTAN PROVINCE
}

\author{
Norma Yuni Kartika $\left(\left(^{*}\right)\right.$, Muhammad Efendi( $\left.{ }^{2}\right)$, Ellyn Normelani( $\left.{ }^{3}\right), \operatorname{Heru}\left({ }^{4}\right)$, Sopyan( $\left({ }^{5}\right)$ \\ 123 Study Program of Geography, FISIP, University of Lambung Mangkurat, South Kalimantan Province \\ ${ }^{4}$ Researcher at Research and Development of Population, Central BKKBN \\ ${ }^{5}$ Junior Expert Population and Family Planning Administration, Representative, of BKKBN South Kalimantan Province
}

\section{ARTICLE INFORMATION}

$\begin{array}{ll}\text { Submitted } & : 01^{\text {st }} \text { November, } 2020 \\ \text { Review } & : 13^{\text {th }} \text { April } 2021 \\ \text { Accepted } & : 26^{\text {th }} \text { May, } 2021 \\ \text { Published } & : 07^{\text {th }} \text { June, } 2021 \\ \text { Available Online } & : \text { June, } 2021\end{array}$

KEYWORDS

Education; Welfare; Residence; Adolescent Marriage; South Kalimantan.

CORRESPONDENCE

E-mail: norma.kartika@ulm.ac.id muhammad.efendi@ulm.ac.id

\begin{abstract}
A B S T R A C T
The low median of age of first marriage in South Kalimantan is partly due to the high number of adolescent marriages that hinder the maturity age of marriage program. Adolescent marriages in this study is the age at first marriage for someone under the age of 20 years. This paper aims to analyze the factors that influence adolescent marriage in South Kalimantan. The study used a crosssectional research design with data from the 2017 Indonesian Demographic and Health Survey (IDHS), South Kalimantan Province. The sample in this study were all married women aged 15-49 years who were respondents to the 2017 IDHS, which were divided into two categories as follows. (1) The category of adolescent marriage was the age of first marriage 15-19 years who met the criteria, amounting to 305 respondents. (2) The category of adult marriage is the age at first marriage of 20 years and over who meets the criteria, amounting to 328 respondents. The analysis in this study used univariable, bivariable and multivariable analysis. The results of the analysis show that 13.3 percent of women with low education, come from poor households and live in rural areas, cause adolescent marriages in South Kalimantan.
\end{abstract}

\section{A. INTRODUCTION}

$\mathrm{P}$ roblems related to population are basically in connection to the quantity, quality and mobility of the population. Referring to Law Number 52/2009 concerning Population Development and Family Development the need for quantity control, quality improvement and direction for population mobility in order to become a formidable resource for national development and resilience has been mandated. Strengthening family quality is one of which indicated by the increase in the Family Development Index and the median age of first marriage for women.

Based on Figure 1, there are four provinces with the lowest median age of first marriage (UKP/Umur Kawin Pertama) for women aged 25-49 years, to be specific Central Kalimantan, South Kalimantan, Gorontalo and Papua with a median of 20.80 years. The median age at first marriage is below the ideal age for marriage and this means that the goal of Marriage Age Maturity Program has not been achieved. Marriage age maturity program is an effort to increase the age of one's first marriage so as to achieve the ideal age for marriage. The ideal age of first marriage in terms of reproductive health, psychology, psychosocial, economy, quality of children born according to the National Population and Family Planning Board, which is known as the Marriage Age Maturity Program, is $21-30$ years for women and $25-40$ years for boys.

The marriage age maturity program is motivated by the many cases of teenage marriages, and many teenage pregnancies are correlated with the number of unwanted pregnancies. This has become the factor of the rapid population growth and also has the potential to decrease the quality of the population. There are many negative impacts which must be 
borne by the adolescents, especially young women when they become teenage marriage subjects. According to Yulkardi, et al (2020) the number of cases of pregnancy outside of marriage encourages people to allow early marriage as a solution to unwanted cases. It is said that the age of marriage is one of the most influential factors on fertility (Davis and Blake, 1974).

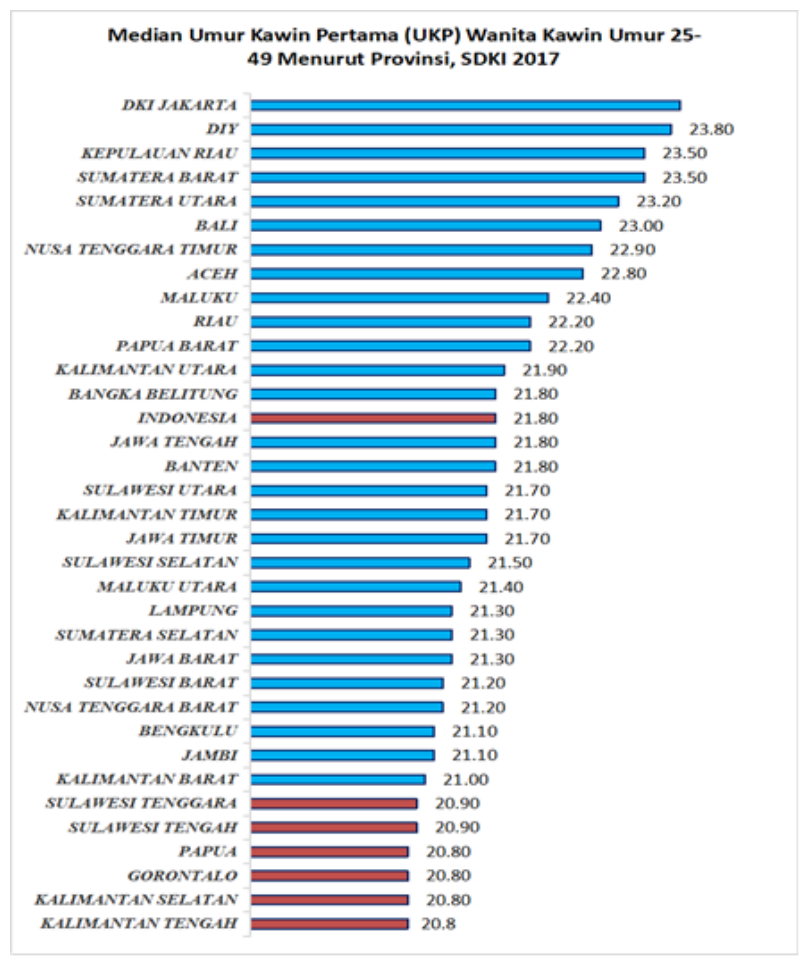

Figure 1 Median Age of Age of First Marriage (UKP) Married Women Aged 25-49 based on Provinces, 2017 IDHS

Adolescence comes from the Latin word adolecere (Dutch word adolesencia which means adolescent) and the word means to grow into adulthood (Hurlock, 1999). The term adolescence has a broad meaning covering mental, emotional, spatial and physical maturity. Adolescence is a transitional period from childhood to adulthood, starting when the child is sexually mature and ending when he/she reaches the legal maturity.

Adolescence is also defined as a developmental period from the transition between childhood to adulthood, which is followed by biological, cognitive and socio-emotional development (Santrock, 2003). According to $\mathrm{WHO}$, adolescent age limit is 15 to 24 years. Meanwhile according to the Indonesian Ministry of Health $a$, a person is considered to be called as a teenager when he/she is between 10 to 19 years old and has not yet married. According to $\mathrm{BKKBN}$, someone is considered to be a teenager when he/she is between the age of 10 to 19 years (Widyastuti, et.al., 2004). Adolescent marriage in this study is the age at first marriage for a person under 20 years of age.
The elimination of adolescent marriages is not only listed in the marriage age maturity program since it is also included in the new global development agenda for the 2016-2030 period which recommends specific targets in the Sustainable Developments Goals (SDGs). One of the SDGs' target is to eliminate forced marriage or child marriage and the SGDs received support from 193 member countries of the United Nations, including Indonesia. In Indonesia, adolescent marriages are violated according to the Marriage Law No. 16/2019. Before the revision of the marriage law, the age limit for a person to get married was regulated in the Marriage Law No. 11974 Article 7 paragraph (1) which explains that marriage is permitted by parents if at least the male subject is 19 and the woman is 16 . After the marriage law is revised to be Marriage Law No. $16 / 2019$, the minimum age limit which is allowed to get married is equally between men and women, at least 19 years old.

Adolescent marriage in Indonesia is caused by structural and cultural aspects. The structural aspect of the causes of teenage marriage is related to the applicable marriage law in Indonesia itself. Article 7 paragraph (1) before being revised indirectly legalizes adolescent marriages. On the other hand, this limitation is a form of violation of rights because someone is too young to make decisions about their marriage partner without understanding the impact of adolescent marriage itself. One of the big issues related to the high incidence of adolescent marriage is related to cultural aspects. The cultural aspect causes the perpetuation of the practice of adolescent marriage in Indonesia because there are still some people who think that the sooner a woman gets married, the better it is for a woman. From a cultural perspective, in several regions in Indonesia, especially remote areas, getting married at a young age is a common practice and is not taboo even though it is not in accordance with the provisions of the marriage law (KPPPA and BPS, 2018).

The purpose of this study is to analyze the factors which influence the adolescent marriage in South Kalimantan. This study uses secondary data with basic data from the 2017 Indonesian Demographic and Health Survey (IDHS) in South Kalimantan province. It is hoped that this secondary data analysis will be able to answer the causes of adolescent marriage from structural and cultural aspects.

\section{B. METHOD}

T he method design used in this study is the cross sectional research design is. The sample in this study were all married women, aged 1549 years who were respondents in the 2017 IDHS in South Kalimantan Province, which there were 633 
respondents in total and they have met the following criteria.

1. The category of adolescent marriage which is the age of first marriage is under 20 years and there are 305 respondents.

2. The category of adult marriage which is the age at first marriage is 20 years and more, and here there are 328 respondents.

The dependent variable in this study is age at first marriage, while the independent variables include residence, education level, economic level and work status. These variables were selected based on the availability of data in the 2017 IDHS.

Table 1 Research Variables and Operational Definitions

\begin{tabular}{|c|c|c|c|}
\hline No & Variables & Operational Definitions & $\begin{array}{l}\text { Scale of } \\
\text { Answers }\end{array}$ \\
\hline \multicolumn{4}{|c|}{ Dependent Variables } \\
\hline 1 & $\begin{array}{l}\text { Age of First } \\
\text { Marriage }\end{array}$ & $\begin{array}{l}\text { Age of first marriage } \\
\text { which is conducts by } \\
\text { someone at the age } \\
\text { below } 20 \text { years } \\
\text { (classification based on } \\
\text { the definition of } \\
\text { adolescents according } \\
\text { to BKKBN) }\end{array}$ & $\begin{array}{l}0= \\
\text { Adolescent } \\
\text { marriages } \\
1=\text { Adult } \\
\text { marriages }\end{array}$ \\
\hline \multicolumn{4}{|c|}{ Independent Variables (Cause of Adolescent Marriages) } \\
\hline 2 & $\begin{array}{l}\text { Residental } \\
\text { Area }\end{array}$ & $\begin{array}{l}\text { Residential area of the } \\
\text { respondents to perform } \\
\text { their daily routine until } \\
\text { the time of the interview } \\
\text { (classification has been } \\
\text { done by BPS, BKKBN, } \\
\text { Ministry of Health and } \\
\text { MI, 2017) }\end{array}$ & $\begin{array}{l}0=\text { Rural } \\
\text { area } \\
1=\text { Urban } \\
\text { area }\end{array}$ \\
\hline 3 & $\begin{array}{l}\text { Level if } \\
\text { Education }\end{array}$ & $\begin{array}{l}\text { Highest level of formal } \\
\text { schooling which has } \\
\text { been taken based on the } \\
\text { length of school and } \\
\text { completed by the } \\
\text { respondent by obtaining } \\
\text { a certificate of school } \\
\text { completion }\end{array}$ & $\begin{array}{l}0=\text { Low } \\
1=\text { High }\end{array}$ \\
\hline 4 & $\begin{array}{l}\text { Level of } \\
\text { Economy }\end{array}$ & $\begin{array}{l}\text { level of family welfare } \\
\text { based on data of } \\
\text { housing characteristics } \\
\text { and ownership of goods, } \\
\text { types of drinking water } \\
\text { sources, toilet facilities, } \\
\text { and other characteristics } \\
\text { related to the socio- } \\
\text { economic status of the } \\
\text { household (classification } \\
\text { and calculation of the } \\
\text { wealth index has been } \\
\text { carried out by BPS, } \\
\text { BKKBN, Ministry of } \\
\text { Health and MI, 2017) }\end{array}$ & $\begin{array}{l}0=\text { Low } \\
1=\text { High }\end{array}$ \\
\hline 5 & $\begin{array}{l}\text { Status of } \\
\text { Employment }\end{array}$ & $\begin{array}{l}\text { doing the work with the } \\
\text { intention of obtaining or } \\
\text { to earn income. }\end{array}$ & $\begin{array}{l}0=\text { Not } \\
\text { working } \\
1=\text { Working }\end{array}$ \\
\hline
\end{tabular}

Phase to the data analysis in this study are as follows. In order to answer the research objective, three phases of data analysis are carried out, namely univariable analysis, bivariable analysis and multivariable analysis. Univariable analysis is performed to see the frequency and distribution of the independent and dependent variables. In Table 1, the frequency is used to describe the proportion of characteristics of the research subject by categorizing the analyzed variables.

Bivariable analysis is carried out to identify whether there is a relation between the independent variable and the dependent variable using the chi square statistical test with a significance level of $p$ value $<0.05$. Meanwhile multivariable analysis is carried out to determine the mutual relationship and hierarchy between the independent variables and the dependent variable using a regression test with a significance level of 95 percent with $p$-value $<0.05$.

\section{RESULTS AND DISCUSSION \\ 1. Characteristics of Respondents based on the Causes of Adolescent Marriages}

\section{a. Residental Area}

$\mathrm{F}$ rom the univariable analysis which has been conducted as shown in Table 2, it is found that the majority of respondents who were married at adolescence age came from rural areas and those who were not married at adolescence age were mostly from the urban areas. This shows that adolescent marriages are more prevalent and experienced by young women in rural areas than in the urban areas. This means that 54 out of 100 women who got married in their teens came from rural areas in South Kalimantan. A similar pattern is also found in BPS and Bappenas (2020) as reported $=$ that the percentage of adolescent marriages in rural areas is 16.78 percent, while in urban areas it is only 7.15 percent.

Table 2 Respondent Frequence Distribution based on the Residental Area

\begin{tabular}{|l|r|r|r|r|}
\hline \multirow{2}{*}{ Residental Area } & \multicolumn{4}{|c|}{ Adolescent Marriages } \\
\cline { 2 - 5 } & \multicolumn{2}{|c|}{ Yes } & \multicolumn{2}{c|}{ No } \\
\cline { 2 - 5 } & $\mathrm{n}$ & \multicolumn{1}{c|}{$\%$} & \multicolumn{1}{c|}{$\mathrm{n}$} & \multicolumn{1}{c|}{$\%$} \\
\hline Rural area & 179 & 53.75 & 154 & 46.25 \\
\hline Urban are & 126 & 42 & 174 & 58 \\
\hline
\end{tabular}

Source: Processed by the authors based on the 2017 IDHS data

\section{b. Level of Education}

Based on the education level of women who got married in their adolescent age, the percentage decreases along with the increase in education level (Table 3). When comparison is made between the education level of women who get married in adolescence and women who ger married in adulthood, the number of women who get married in their teens has lower education. Adolescent marriages will not think long in deciding their marriage as long as they love each other, but they do not think about the impact and future of marriage at a 
young age (Taufan and Rosramadhana, 2016). In contrast to women who get married at adulthood, they have a higher education. This finding strengthens the hypothesis which has been proven by BPS and Bappenas (2020) and stated that women who have married at the adolescent age tend to have a lower level of education than those who married at adulthood.

Data on the education of respondents in the 2017 IDHS is educational data during the survey. There is no data presenting the education level before the marriage and after the marriage. There are 3.53 percent of women who get married in their teens who have a university diploma. It is possible that even though she was married in her teenage years, she continued her education to a higher level. The woman is also able to prove that marriage does not take away her human rights, especially in education.

Table 3 Respondent Frequence Distribution based on the Level of Education

\begin{tabular}{|l|r|r|r|r|}
\hline \multirow{2}{*}{\multicolumn{1}{|c|}{ Education }} & \multicolumn{4}{|c|}{ Adolescent Marriages } \\
\cline { 2 - 5 } & \multicolumn{2}{|c|}{ Yes } & \multicolumn{2}{c|}{ No } \\
\cline { 2 - 5 } & $\mathbf{n}$ & \multicolumn{1}{c|}{$\%$} & \multicolumn{1}{c|}{$\mathbf{n}$} & \multicolumn{1}{c|}{$\%$} \\
\hline Not attending school & 9 & 75 & 3 & 25 \\
\hline $\begin{array}{l}\text { Not graduated from } \\
\text { Elementary School }\end{array}$ & 72 & 75 & 24 & 25 \\
\hline $\begin{array}{l}\text { Graduated from } \\
\text { Elementary School }\end{array}$ & 77 & 63.64 & 44 & 36.36 \\
\hline $\begin{array}{l}\text { Not Graduated from High } \\
\text { School }\end{array}$ & 121 & 64.02 & 68 & 35.98 \\
\hline $\begin{array}{l}\text { Graduated from High } \\
\text { School }\end{array}$ & 23 & 17.69 & 107 & 82.31 \\
\hline University & 3 & 3.53 & 82 & 96.47 \\
\hline
\end{tabular}

In contrast to women who are not married at adolescence, the percentage increases along with increasing level of education completed. Women who are able to complete the 12 years of compulsory education guarantee that by attending school, it allows women to enjoy their adolescence and that their human rights in education are fulfilled. This finding is in accordance to the reports of BPS and Bappenas (2020) states that almost half (45.56 percent) of women who are married in adulthood complete the senior high school level. BPS and UNICEF (2016) state that investing in secondary school education for girls, especially to complete high school, is one of the best ways to ensure that girls will reach the adulthood before marriage.

From the figures in Table 3 , the majority of women who get married in the adolescent drop out of school at the elementary and high school levels, as for women who do not get married in the adolescent, the majority are able to complete the high school level. The percentage of women who get married as teenagers and do not go to school is 75 percent. This means that at least 75 out of 100 women who get married in their teens have never gone to school. BPS (2017) shows that girls who have low education and drop out of school are generally more prone to get married at child age than those with secondary and tertiary education. BPS and UNICEF (2016).

\section{c. Type of Employment}

Type of employment for women who get married at adolescence is shown in Table 4. The highest three percentages of the highest sequence are working in the agricultural sector, working in the service business and those who are not working. This means that 49 out of 100 women who get married at the adolescent do not work. The low employment participation of women who get married at adolescence is partly due to the low level of education which they have completed, and it results in their losing competitiveness in the world of labor. BPS (2017) in the report states that adolescent marriages can affect the labor force participation.

Table 4 Respondent Frequence Distribution based on the Type of Employment

\begin{tabular}{|c|c|c|c|c|}
\hline \multirow{3}{*}{ Type of Employment } & \multicolumn{4}{|c|}{ Adolescent Marriages } \\
\hline & \multicolumn{2}{|c|}{ Yes } & \multicolumn{2}{|c|}{ No } \\
\hline & $\mathrm{n}$ & $\%$ & $\mathrm{n}$ & $\%$ \\
\hline Not working & 90 & 48.65 & 95 & 51.35 \\
\hline Professional, technician & 6 & 12.50 & 42 & 87.50 \\
\hline Managers and administration & 1 & 25.0 & 3 & 75.0 \\
\hline Religious leaders & 2 & 13.33 & 13 & 86.67 \\
\hline Marketing staff & 78 & 46.43 & 90 & 53.57 \\
\hline Service staff & 29 & 54.72 & 24 & 45.28 \\
\hline Agriculture & 89 & 66.42 & 45 & 33.58 \\
\hline Industrial workers & 10 & 38.46 & 16 & 61.54 \\
\hline
\end{tabular}

Source: processed by the authors based on the 2017 IDHS data

Meanwhile, the characteristics of the types of employment for those who did not get married at adolescents, seeing in order of the highest percentage, are working as a professional/technician, working as a religious leader and working as an industrial worker. In the type of employment in the agricultural sector, when compared between those who are married in adolescents and those who are not, there is no significant differences. Women who get married as adolescents and work in the agricultural sector are twice in number compared to those who are get married older. Indeed this is related to the high number of respondents who get married in their teens and come from rural areas. It is known that the community in rural areas is identical to the type of employment in the agricultural sector. BPS and Bappenas (2020) in their report state that there is something interesting which is shown in the agricultural sector, around 33.16 percent of female workers aged 20-24 years who are married before the age of 18 work in this sector. Meanwhile, for female workers aged 20-24 who are married at the age of 18 and more, only around 18.86 percent work in the agricultural sector. 
For both groups of women, there are more women in the group of those getting married older which do not work compared to those in the group of adolescent marriages. When they have to work, women who get married as teenagers work in the agricultural sector, while those who do not get married in their teenagers mostly work as professionals/technicians. BPS and Bappenas (2020) state that working women aged 18 years and under are more likely to work in the informal sector and are therefore more vulnerable when compared to women in the same age group who get married after 18 years and go to work.

\section{d. Household Wealth Index}

From Table 5, it shows that the percentage of wealth index of the women who get married in their teens is decreasing along with the increase in welfare, from 58.50 percent of the lowest wealth index to decreasing to 23.86 percent in the top wealth index. The opposite characteristic generally occurs in women who do not get married in their adolescents, to be specific that the percentage increases with the increase in the wealth index. It is from 41.50 percent on the lowest wealth index to 76.14 percent on the top wealth index. The same pattern is found in BPS and Bappenas (2020) reports which state that based on the level of welfare, women aged 20-24 years who come from households with the lowest welfare level tend to be more likely to get married at the age of under 18 years. Meanwhile, those from households with the highest welfare level had the lowest prevalence of having married before the age of 18 .

Adolescent marriages in South Kalimantan also occur in the top wealth index of 23.86 percent, which means that 24 out of 100 adolescents who come from rich families get married in their teens. This finding is in line with the study of Fadlyana and Larasaty (2016), which state that in general, adolescent marriage is more common among poor families although it also occurs among the highincome families. In many countries, adolescent marriage is often linked to poverty. Dewi and Dartanto (2019) who studied about the vulnerable children and adolescents, one of which is teenagers getting married, is considered to be a response to family economic shocks, but in fact, it is the opposite which occurs.

Table 5 Respondent Frequence Distribution based on Household Wealth Index

\begin{tabular}{|c|c|c|c|c|}
\hline \multirow{3}{*}{$\begin{array}{l}\text { Household Wealth } \\
\text { Index }\end{array}$} & \multicolumn{4}{|c|}{ Adolescent Marriages } \\
\hline & \multicolumn{2}{|c|}{ Yes } & \multicolumn{2}{|c|}{ No } \\
\hline & $n$ & $\%$ & $\mathrm{n}$ & $\%$ \\
\hline Lowest & 86 & 58.50 & 61 & 41.50 \\
\hline Middle Low & 85 & 55.92 & 67 & 44.80 \\
\hline Middle & 83 & 54.25 & 70 & 45.75 \\
\hline Middle Up & 30 & 32.26 & 63 & 67.74 \\
\hline Highest & 21 & 23.86 & 67 & 76.14 \\
\hline
\end{tabular}

Source: processed by the authors based on the 2017 IDHS+

\section{Bivariable Analysis of the Cause of Adolescent Marriages}

Furthermore to determine the relation between variables, bivariable analysis will be carried out. Bivariable analysis is a follow-up analysis of the univariable analysis by cross tabulation between the independent and dependent variables. To determine whether there is a significant relation between the independent variables (residential area, education, employment status and economy) to the dependent variable (adolescent marriages), a Chi Square test is performed. An independent variable is stated to have a significant relation if the statistical test results obtained $p$ value $<0.05$. Of the four variables tested according to Table 6 , there are three significant variables: residental area, education and economy. There is one variable which is not significant, to be spesific employment status because the $p$ value is> 0.05 . Hereafter, three significant variables in the bivariate analysis can be continued to the multivariate analysis.

Table 6 Relation between Residental Area, Education, Employment Status and Economy to the Adolescent Marriages

\begin{tabular}{|c|c|c|c|c|c|c|c|}
\hline \multirow{2}{*}{ No } & \multirow{2}{*}{ Variables } & \multicolumn{2}{|c|}{$\begin{array}{l}\text { Adolescent } \\
\text { Marriages }\end{array}$} & \multirow{2}{*}{$\begin{array}{l}\text { Value } \\
\text { of } \\
x^{2} \text { coumt }\end{array}$} & \multirow{2}{*}{ Df } & \multirow{2}{*}{$\begin{array}{l}\text { Value } \\
\text { of } \\
x^{2} \text { Tabls }\end{array}$} & \multirow{2}{*}{$\begin{array}{l}\text { Value } \\
\text { of Sig. }\end{array}$} \\
\hline & & $\begin{array}{l}\text { Yes } \\
(\%)\end{array}$ & $\begin{array}{l}\text { No } \\
\text { (\%) }\end{array}$ & & & & \\
\hline 1. & $\begin{array}{l}\text { Residental Area } \\
\text { Rural Area } \\
\text { Urban Area }\end{array}$ & $\begin{array}{r}53.75 \\
42\end{array}$ & $\begin{array}{r}46.25 \\
58\end{array}$ & $8.733^{*}$ & 1 & 3.84 & $0.003^{*}$ \\
\hline 2. & $\begin{array}{l}\text { Education } \\
\text { Low } \\
\text { High }\end{array}$ & $\begin{array}{r}69 \\
36.39\end{array}$ & $\begin{array}{r}31 \\
63.61\end{array}$ & $9.818^{*}$ & 1 & 3.84 & $0.002^{*}$ \\
\hline 3. & $\begin{array}{l}\text { Status of } \\
\text { Employment } \\
\text { Not Working } \\
\text { Working }\end{array}$ & $\begin{array}{l}48.65 \\
47.99\end{array}$ & $\begin{array}{l}51.35 \\
52.01\end{array}$ & $0.023^{*}$ & 1 & 3.84 & 0.880 \\
\hline 4. & $\begin{array}{l}\text { Wealth Index } \\
\text { Lotvest } \\
\text { Highest }\end{array}$ & $\begin{array}{l}57.19 \\
40.12\end{array}$ & $\begin{array}{l}42.81 \\
59.88\end{array}$ & $18.144^{*}$ & 1 & 3.84 & $0.001^{*}$ \\
\hline
\end{tabular}

Source: processed by the authors based on 2017 IDHS data Note: * is significant at 0.05 .

\section{a. Relation between the Residental Area and Adolescent Marriages}

From the analysis which has been conducted, it shows that the majority of respondents who got married at their teen came from rural areas (53.75 percent) and the majority of respondents who did not perform teenage marriages came from urban areas (58 percent). The result of statistical test, the value of $p=0.003 \leq 0.05$, means that there is a relation between the residential area and adolescent marriages. This shows that women coming from rural areas are related to the adolescent marriages.

\section{b. Relation between Education and Adolesent Marriages}

From the results of the analysis as seen in Table 6 , it shows that there is no significant differences in the education level of the majority women who got 
married in the teens and those who did not, to be specific 69 percent of the women getting married in their teens had low education and 63.61 percent of women getting married at older age had high education. Low education means that the respondents do not go to school, have not graduated from elementary school and have graduated from elementary school, while high education means that the respondents have graduated from junior high school and above. The result of statistical test, the value of $p=0.002 \leq 0.05$, means that there is a relation between education and adolescent marriages. This shows that low education is related to adolescent marriages.

\section{c. Relation between Employment Status and Adolscent Marriages}

From the analysis, it shows that the respondents who got married in their teens is 48.65 percent and it is the majority of those who are not working. Meanwhile women who got married at an older age, 52.01 percent of them are working (Table 6). The result of statistical test, $p$ value $=0.880 \geq 0.05$, means that there is no relation between employment status and adolescent marriages. BPS and Bappenas (2020) state that most of the female workers aged 20-24 years have been married, they work in the service sector, whether they are married before the age of 18 years or at the age of 18 years and over.

\section{d. Relation between Wealth Index and Adolescent Marriages}

Result of the analysis in Table 6 shows that the majority of women who got married in their teens come from families with the lowest wealth index (57.19 percent), while the majority of women who got married at an older age come from families with the highest wealth index (59.88 percent). The result of statistical test, the value of $p=0.001 \leq 0.05$, means that there is a relation between wealth index and adolescent marriages. This shows that women coming from families with the lowest wealth index have a relation with adolescent marriages.

\section{Multivariable Analysis}

Multivariable analysis is conducted to determine the effect of independent variables (education, economy and residential area) on the dependent variable (adolescent marriages). This analysis is conducted to select the independent variables which had a significant effect on adolescent marriages. The magnitude of the risk of adolescent marriages is seen from the odds ratio (OR) with a significance level of $p$ $<0.05$. The OR value of the reference category is 1.Thus, if the OR value $<1$ (less than one: smaller than the reference category), it is interpreted as having a low tendency, while the OR value> 1 (greater than 1: greater than category being the reference) is interpreted as having a strong tendency.

Table 7 Result of Multivariable Analysis of the Cause of Adolescent Marriages in South Kalimantan.

\begin{tabular}{|l|r|}
\hline \multicolumn{1}{|c|}{ Variables } & \multicolumn{1}{|c|}{$\begin{array}{c}\text { Model 4 } \\
\text { OR }\end{array}$} \\
\hline Education & $\begin{array}{r}3.4^{*} \\
(2.379-4.990)\end{array}$ \\
\hline Economy & $1.3^{*}$ \\
& $(0,893-1,835)$ \\
\hline Residental Area & $1.1^{*}$ \\
\hline B & $(0.804-1.613)$ \\
\hline Significant Value (P) & 1.237 \\
\hline$R^{2}$ & $0.000^{*}$ \\
\hline
\end{tabular}

Source: processed by the authors based on 2917 IDHS data

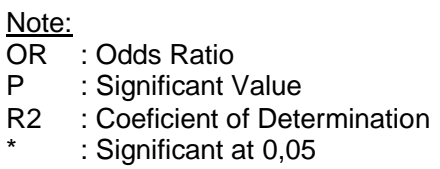

Based on the results of the multivariable test analysis in Table 7 , it is known that the variables of education, economy and residential area are the independent variables causing the adolescent marriages. Of the four multivariable analysis models, the fourth model is the most complete one since it includes the three variables which have passed the bivariable analysis stage. From the value of the coefficient of determination in model 4 , it shows that women with low education, come from poor households and live in rural areas (13.3 percent) cause adolescent marriage in South Kalimantan.

The finding reinforces the previous findings, namely the findings in the BPS and Bappenas (2020) report, Susenas and literature studies which show that children who are vulnerable to the adolescent marriages are girls living in the poor families, in rural areas and have low education. Djaja, et.al. (2016) studied that one of the policies which can erode child marriage is the marriage age maturity program. UNICEF (2017a) discusses the education as one of the variables to end adolescent marriages in Bangladesh.

\section{a. Effect of Educational Variables on Adolescent Marriages}

In their paper, BPS and Bappenas (2020) link the adolescent marriages to education. However, the data listed cannot show a cause-and-effect correlation between the two aspects. This means that it is not yet certain whether marriage is a factor in dropping out of school or due to the fact that children drop out of school, the practice of adolescent marriage occurs. The same thing happened in this study due to the lack of data held. Data in the 2017 IDHS which is the basic data for the analysis of this study does not have data on education before and after marriage. 
Based on the results of the multivariable test, it shows that there is an influence of education to the occurrence of adolescent marriages. Table 7 shows that those with low education or elementary school completion and below are 3.4 times more likely to be involved in the adolescent marriages. It should be underlined that education can be an approach to prevent adolescent marriages. However adolescent marriage is not only caused by low education. Adolescent marriage also violates a number of human rights guaranteed by the Convention on the Rights of the Child (KHA/ Konvensi Hak Anak), one of which is the right to have an education. Adolescent marriages abuse the children's right to education, to play with their peer group and to fulfill their potential because it can interfere with or end their education process.

The Indonesian government posseses a twelve year compulsory education program. If this program is successful, the case for adolescent marriages will automatically decrease and the rights in the field of children's education will be fulfilled which means that the human rights are obtained. Research from Dewi and Dartanto (2019) suggest that the existence of secondary schools and training reduces the possibility of girls marrying at the teen age. Each addition of one of these facilities can reduce the likelihood of adolescent marriage to occur by 1.3 percentage points (secondary school) and 0.46 percentage points (training institutions). Other studies which are in line with the results of this study show that low education causes women to be prone to marrying at a young age, include Rumble, et.al. (2018); UNICEF. (2017b); Paul (2019); and BPS and Bappenas (2020). Olivera (2018) also suggests that empowering girls starts with providing the proper sexuality education.

\section{b. Effect of Economic Variables to the Adolescent Marriages}

Based on the results of the multivariable test, it shows that there is an influence of the economy to the occurrence of adolescent marriages. Table 7 shows that poverty tends to be 1.3 times greater for the chance to adolescent marriages to occur. This finding strengthens the findings of previous researchers, namely Marshan et.al. (2013); Parsons Jennifer et.al. (2015); Fadlyana and Larasaty (2016); Jennifer, et.al. (2015); Credos Institute (2017); Wodon, et.al/ (2018); Dewi and Dartanto (2019); Paul (2019). It is known that in many countries, adolescent marriages are often linked to poverty. UNICEF (2017a) shows that poverty is a major driver of adolescent marriage to women in developing countries. Benedicta, et.al. (2017) studies that poor family conditions make children considered as an economic burden so that adolescent marriage is the only solution to reduce this burden. BPS and Bappenas (2020) based on data from Susenas in March 2018 show a slight difference in the poverty level between women aged 20-24 who get married before 18 years of age (13.76 percent) and those who get married older than 18 years (10.09 percent). This can mean that poverty is a factor driving the practice of adolescent marriages, but it is not the main or the only factor of it.

\section{c. Influence of Residential Area Variables to the Adolescent Marriages}

Based on the results of the multivariable test, it shows the influence of the residential area to the occurrence of adolescent marriages. Table 7 shows that respondents from rural areas are 1.1 times more likely to be involved in the adolescent marriages. This finding strengthens the report on child marriage of BPS and Bappenas (2020) which states that disaggregation by residential area shows that the prevalence of marriage for girls is higher in rural areas than in urban areas. This is especially an evident in the group of age of first marriage before the age of 18 and before the age of 15. Girls in rural areas are twice as likely to be married compared to girls in urban areas. Rumble, et.al. (2018) states that the factor causing adolescent marriage is the residential area in rural areas. In their study, Marshan, et.al. (2013) found that girls living in urban areas are more likely to get opportunities outside of marriages and childcare than those in rural areas. BPS and Bappenas (2020) in their report state that disaggregation by residential area shows that the prevalence of girl marriages is higher in rural areas compared to the urban areas.

\section{CONCLUSIONS}

$\mathrm{T}$ he causes of adolescent marriages in South Kalimantan based on the analysis of the 2017 IDHS data will include graduating from elementary school and below, coming from families with the lowest wealth index and living in rural areas. The three findings in this study are the causes of adolescent marriage from a cultural aspect, due to the limited data available on secondary data so that the variables adjust to the available data.

The proper strategies to accelerate the achievement of the maturity program for first marriage in South Kalimantan will include the adolescent population to be required to complete the 12 year basic education program, strengthening the child protection system, child welfare in social assistance and protection programs, and child care so that they are not trapped in poverty. Furthermore, socialization on the dangers and negative impacts of the culture of early marriage must be provided to prevent the adolescent marriages which are still practiced by people in rural South Kalimantan. Last but not the least is to marry in accordance with the minimum age for marriage, which refers to Law No. 16/2019 concerning marriage in Indonesia. 


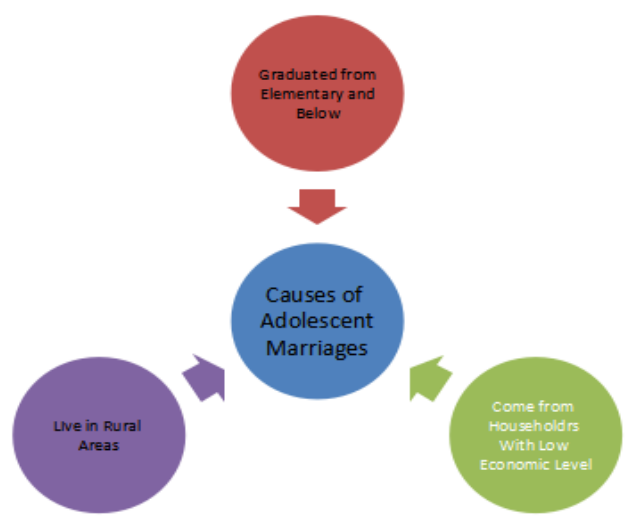

Figure 2 Causing Factors of Adolescent Marriages in Soouth Kalimantan based in 2017 IDHS Data

\section{E. ACKNOWLEDGMENT}

$\mathrm{T}$ he authors will like to express the gratitude to the Central National Population and Family Planning Agency (BKKBN/Badan Kependudukan dan Keluarga Berencana Nasional) and South Kalimantan Province Representative Office of BKKBN, also the appreciation for the cooperation. Thank you for the Head of Study Program and colleagues at Geography Study Program, Faculty of Social Science and Politic Science, ULM.

\section{REFERENCES}

Anggriyani, D. S., \& Dartanto, T. (2019). Unity in Diversity: Socioeconomic Aspects and Growth of Conflict in Indonesia. International Journal of Business and Society 20.

Badan Pusat Statistik, \& UNICEF. (2016). Analisis Data Perkawinan Usia Anak di Indonesia. Unicef Indonesia. https://doi.org/978-978-064-963-6

Badan Pusat Statistik (BPS), Badan Koordinasi Keluarga Berencana Nasional (BKKBN), Kementrian Kesehatan, dan Macro International Inc. (MI). 2017. Survei Demografi dan Kesehatan Indonesia 2017. Calverton, Maryland, USA: BPS dan MI.

Badan Pusat Statistik (BPS). (2017). Perkawinan Usia Anak di Indonesia. The British Journal of Psychiatry. https://doi.org /10.1 19 2/bjp.112.483.211-a

Benedicta, G. D., Noor, I. R., Kartikawati, R., Zahro, F. A., Susanti, L. R., Natih, N. N. S., \& Ramadhan, F. R. (2017). Studi Kualitatif 'Yes I Do Alliance' (YID) . Faktor Penyebab dan Konsekuensi Perceraian setelah Perkawinan Anak di Kabupaten Sukabumi, Rembang dan Lombok Barat.

Davis, K., \& Blake, J. (1956). Social Structure and Fertility: An Analytic Framework. Economic Development and Cultural Change. https://doi.org/10.1086/449714

Dibb, Paul. (2019). Australia's strategic risks are changing and so must our defence thinking. The Australian.

Fadlyana, E., \& Larasaty, S. (2016). [Problems around underage marriage]. Sari Pediatri. https://doi.org/ $10.14238 / \mathrm{sp} 11.2 .2009 .136-41$

F.A.O; FIDA; OMS, PMA, U. (2017). El estado de la seguridad alimentaria y la nutrición en el mundo. In SOFIA2018-estado de la seguridad alimentaria.

González, Iván; Galván, María Quetzalcihautl; Pérez, Gerardo; Olivera, A. (2018). Análisis del capital humano en el área de logística de las MiPyMES de los sectores más destacados del municipio de Durango. In Administración y Negocios en Latinoamerica 2018.

Heer, D. M., Davis, K., \& Blake, J. (2019). Social Structure and Fertility: An Analytic Framework. In Kingsley Davis. https://doi.org/10.4324/9780203787724-21

Hurlock. (2019). Usia anggota dewan direksi. Fakultas Ekonomi Manajemen Universitas Islam Indonesia.

Kementerian BPN/BAPPENAS, Badan Pusat Statistik, U. (2018). Proyeksi Penduduk Indonesia 2015-2045: Hasil SUPAS 2015. In Badan Pusat Statistik.

Kumala Dewi, L. P. R., \& Dartanto, T. (2019). Natural disasters and girls vulnerability: is child marriage a coping strategy of economic shocks in Indonesia? Vulnerable Children and Youth Studies. https://doi.org/10.1080/17450128.2018.1546025

Manlove, J., Ikramullah, E., \& Terry-Humen, E. (2008). Condom Use and Consistency Among Male Adolescents in the United States. Journal of Adolescent Health. https://doi.org/10.1016/j.jadohealth.2008.03.008

Norcross, J. C., Santrock, J. W., Campbell, L. F., Smith, T. P., Sommer, R., \& Zuckerman, E. L. (2003). Authoritative guide to self-help resources in mental health (rev. ed.). [References]. In (2003).

Onishhenko, G. G., Ezhlova, E. B., Demina, Y. V., Kulichenko, A. N., Savel'Ev, V. N., Agapitov, D. S., Volynkina, A. S., Kuznetsova, I. V., Taran, T. V., Efremenko, D. V., Belyaeva, A. I., Marshan, Z. G., Polikhova, L. M., Bartsits, V. V., \& Orobej, V. G. (2015). Epidemic Outbreak of a Shigellosis Zonne in the Republic Abkhazia in 2013. Epidemiology and Vaccine Prevention. https://doi.org/10.31631/2073-30462015-14-2-26-30

Paul Dibb, 2019. Australia's strategic risks are changing and so must our defence thinking. The Australian.

25 | P a g e

https://doi.org/10.25077/jantro.v23.n1.p18-26.2021

NORMA YUNI KARTIKA , ET AL 
Perempuan, K. P. (2018). Profil anak indonesia 2018. Jakarta (ID): KPPA.

Requejo, J. H., \& Bhutta, Z. A. (2015). The post-2015 agenda: Staying the course in maternal and child survival. Archives of Disease in Childhood. https://doi.org/10.1136/archdischild-2013-305737

Son, S. J., Lee, K. S., Lee, Y., Baek, J. H., Choi, S. H., Na, D. L., Seo, S. W., Oh, B. H., \& Hong, C. H. (2012). Association between white matter hyperintensity severity and cognitive impairment according to the presence of the apolipoprotein $\mathrm{E}$ (APOE) $\varepsilon 4$ allele in the elderly: Retrospective analysis of data from the CREDOS study. Journal of Clinical Psychiatry. https://doi.org/10.4088/JCP.12m07702

Taufan, N., \& Rosramadhana, R. (2016). Fenomena Perkawinan Dini di Kalangan Perempuan Jawa Deli-Deli Serdang. Anthropos: Jurnal Antropologi Sosial dan Budaya (Journal of Social and Cultural Anthropology), 2(1), 62-75.

Undang-undang No. 1. (1974). Perkawinan. In Republik Indonesia.

Undang-undang No. 16. (2019). Perkawinan. In Republik Indonesia.

UNICEF. (2017a). A simplified version of the United Nations Convention on the Rights of the Child. The United Nations Convention on the Rights of the Child.

UNICEF. (2017b). The Adolescent Brain: A second window of opportunity. The Adolescent Brain: A Second Window of Opportunity.

UNICEF, BPS, PPN/Bappenas, K., PUSKAPA, \& INDONESIA, U. (2020). Pencegahan Perkawinan Anak Percepatan yang Tidak Bisa Ditunda. Badan Pusat Statistik.

UNICEF, \& World Health Organization. (2018). Implementation Guidance; Protecting, promoting and supporting Breastfeeding in facilities providing maternity and newborn services: the revised BABY-FRIENDLY HOSPITAL INITIATIVE. In WHO.

Widyastuti, \& Dkk. (2004). Pengaruh Motivasi terhadap Terhadap Minat Mahasiswa Akuntansi Untuk Mengikuti Pendidikan Profesi Akuntansi (Ppak). SNA-Seminar Nasional Akuntansi.

Wodon, Quentin T.; Male, Chata; Onagoruwa, Adenike Opeoluwa; Savadogo, Aboudrahyme; Yedan, Ali; Kes, Aslihan; John, Neetu; Steinhaus, Mara; Murithi, Lydia; Edmeades, Jeff; Petroni, Suzanne. 2018. Economic impacts of child marriage: Ethiopia synthesis report (English). The Economic Impacts of Child Marriage. Washington, D.C.: World Bank Group.

Yulkardi, Y., Jelly, J., \& Yunarti, Y. (2020). Pernikahan Usia Anak: Manifestasi Disfungsi Sistim Tali Tigo Sapilin dalam Masyarakat di Nagari Sialang, Kabupaten 50 Kota, Sumatera Barat. Jurnal Antropologi: Isu-Isu Sosial Budaya, 22(2), 264-275. 